\title{
Repurchase Dividend Reinvestment Plans (Repurchase DRIPS)
}

Patrick Larkin, (Email: plarkin@uncfsu.edu), Fayetteville State University

Baeyong Lee, (Email: blee@uncfsu.edu), Fayetteville State University

Abdoul Wane, (Email: awane@uncfsu.edu), Fayetteville State University

\begin{abstract}
We investigate the determinants of firms' decision to offer Repurchase Dividend Reinvestment Plans (Repurchase DRIPs). Firm size, managerial share holding, and free cash flow are statistically significant in explaining a firm's decision to employ Repurchase DRIPs. We find that managerial stock ownership is negatively related to use of Repurchase DRIPs. Economies of scale in marketing and maintaining DRIP program and excess cash flows are positively related to Repurchase DRIP adoption. We find no evidence that information asymmetry is a major motivation to the likelihoods of using Repurchase DRIPs.
\end{abstract}

\section{INTRODUCTION}

D

ividend Reinvestment Plans (DRIPs) allow investors to reinvest dividends in additional shares of a firm's common stock instead of sending dividend checks to shareholders enrolled in the company's DRIP. A shareholder usually needs only one share to enroll in a company's DRIP plan, and most of the time the company will reinvest a shareholder's dividends without a fee or commission. DRIPs have been in existence since at least the 1950s (Cherin and Hanson, 1995) and continue to gain popularity. Today over 1800 companies and most Fortune 500 firms offer DRIPs with approximately five million investors enrolled in them (Berry, 2000). These companies include Dow industrial stocks like IBM and McDonald's. A most recent example is Microsoft, which on 16 January 2003 announced its first dividend of $\$ 0.16$, offered its shareholders the opportunity to reinvest in Microsoft shares through a DRIP.

DRIPs are generally classified into two types based on the shares used in the plan; New Dividend Reinvestment Plan (henceforth New DRIP) that distribute newly-issued shares, and Repurchase Dividend Reinvestment Plan (henceforth Repurchase DRIP) that uses outstanding shares repurchased by the firm in the open market. While many companies sponsor and administer their own DRIP, some companies choose to contract with a bank as the sponsor of the DRIP. In the case of bank-sponsored DRIPs, the stock purchased with reinvested dividends comes from the open market. The fees charged by Repurchase DRIP tend to be slightly higher, when compared to New DRIP since a DRIP sponsoring bank usually administers Direct Stock Purchase Plan (DSPP) as well. DSPPs allow anyone to buy shares from the company directly. Following that initial purchase, the DSPP operates just like any dividend reinvestment plan.

Our investigation reveals that overwhelming majority of DRIPs (882 out of 963) use repurchased shares. This is somewhat surprising because Repurchase DRIPs do not increase the firm's capital level to finance growth opportunities, which is regarded by many as one of DRIPs' primary objectives. Our research investigates the determinants of firm's decision to offer Repurchase DRIPs by examining the cross-sectional differences of firm's motivations to offer Repurchase DRIPs vis-à-vis control firms from the same industries that do not offer DRIPs.

The rest of the paper is organized as follows: Section II develops the hypotheses. Section III describes our data and methodology. Section IV presents the empirical results, and Section V concludes the paper. 


\section{HYPOTHESES DEVELOPMENT}

Even though dividend reinvestment plans have become popular among U.S. corporations, it is still a puzzle, “Why firms offer DRIPs?” Baker and Seippel (1980), Carlson (1992), Davey (1976), Fox (1981), Hagaman (1992), Pettway and Malone (1973), and Rodgers (1980), provide the main economic motivations for firms to offer DRIPs. First, firms employ DRIPs to improve shareholder relations, as participating shareholders are able to increase their holdings at a relatively low cost. The use of DRIPs stabilizes the stockholder base by maintaining a steady demand for the firm's common stock. This base of individual shareholders can help stabilize a company's share price. DRIPs reduce dependence on debt financing, as capital is retained inside the company, by not paying cash dividends outright and having those dividends reinvested in additional share purchases. As the firm grows, DRIPs can be used as a cheaper source of financing since DRIPs help companies to raise additional capital without making a public offering. Therefore DRIPS lower the firm's financing costs. We hypothesize that firm's decision to adopt Repurchase DRIPs can be predicted by firms' characteristics including information asymmetry, managerial ownership, free cash flow, and firm size. We use logit regression model to assess the relationship between firms' characteristics and the likelihood that firms offers Repurchase DRIPs.

\section{Information Asymmetry}

Considerable evidence suggests that the payment of dividends provides information that helps investors and analysts value the firm. For example, Healy and Palepu (1988) and Miller and Rock (1985) show that there is a positive relationship between dividend changes and stock price. Dividend change signals information about cash flows and/or future investments of a firm. Therefore, managers are reluctant to reduce or omit dividend payments. The argument is based on the idea that managers are better informed than the market about the true value of the firm. The information asymmetry between managers and outsiders may cause a firm to be misvalued. Thus, firms that are more likely to be misvalued are more likely to repurchase stocks in order to exploit the information asymmetry. Repurchase DRIPs enable firms keep paying dividends to shareholders in forms of market shares. The degree of information asymmetry is measured by market-to-book ratio.

\section{Insider Ownership}

Davey (1976) and Skully (1982) suggests that for corporations aiming to restrict excessive institutional ownership, a DRIP would attract small individual shareholders, keeping control in hands of management and thus reducing the likelihood of an unwanted takeover. Dispersion of ownership among outside stockholders may influence the likelihood of adopting DRIPs, with more dispersion leading to lower likelihood. Bagwell (1991) and Ditter (2000) suggest that a repurchase can be used as an unwanted takeover defense since repurchases increase the acquisition price. As a result, firms with less managerial ownership are more likely to offer Repurchase DRIPs.

\section{Free Cash Flow Hypothesis}

Jensen (1986) suggests that when a firm's level of cash flow exceeds its investment opportunities with positive Net Present Value (NPV), conflicts of interest between shareholders and managers over payout policies become severe. According to this free cash flow hypothesis, a dividend increase by a firm with excess capital would reduce the market's estimate of amount of cash that would be wastefully invested, thereby increasing firm value. Similarly, a dividend decrease by such a firm would convey a signal that more negative NPV projects would be undertaken, decreasing firm value. Bajaj and Vijh (1990), Kaplan and Reishus (1990), and Denis, Denis, and Sarin (1994) suggest that repurchasing stock is a more flexible choice of distributing capital since a penalty is severe if dividend payouts are subsequently reduced. Repurchase DRIP is a good mean of distributing excess capital since stock repurchase and dividend payments are offered to investors at the same time. As a result, a firm with excess cash flow may find it beneficial to use Repurchase DRIPs as means of distributing excess capital. 


\section{Firm Size}

Costs also play a role in a firm's decision to offer DRIPs and in the choice among DRIPs strategies. Skully (1982), Davey (1976), Carlson (1992) argue that there are high costs associated with initiating, administering, and maintaining DRIPs. The costs are associated with choosing a particular DRIP program and even educating shareholders when initiating DRIPs. Economies of scale in the costs of maintaining DRIPs present an opportunity that may be beneficial to larger firms. The likelihood of adopting DRIPs due to economies of scale in the costs would be greater for larger firms. Firm size is computed as the natural log of the market value of its equity. Table 1 contains a summary of the explanatory variables, their abbreviations in the model, and predicted signs.

\section{METHODOLOGY AND DATA}

In this paper, we explore the cross-sectional variations in the factors to influence a firms' decision to offer Repurchase DRIPs. Logistic regression is useful for situations where the dependent variable is dichotomous. The probability that firms adopt Repurchase DRIPs can be written as follow.

$\operatorname{Prob}(\mathrm{Y}=1)=\mathrm{F}(\mathrm{Z})$

$\operatorname{Prob}(\mathrm{Y}=0)=1-\mathrm{F}(\mathrm{Z})$

Where $\mathrm{Y}$ is dichotomous dependent variable; $\mathrm{F}$ is the cumulative distribution function; and $\mathrm{Z}$ is a vector of parameters and independent variables. If the cumulative distribution is logistic, then we can have

$\mathrm{F}(\mathrm{Z})=\exp (\mathrm{Z}) /(1+\exp (\mathrm{Z}))$

Since 1- $F(-Z)=F(Z)$, we can write Prob $(Y=1)$ equals $F(Z)$.

The following logit regression function is used to test the explanatory capabilities of the hypothesized characteristics.

$\operatorname{Prob}(\mathrm{Y}=1)=\exp (\mathrm{Z}) /(1+\exp (\mathrm{Z}))$

where

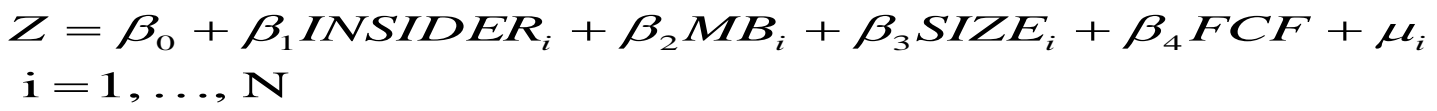

The dependent variable is an indicator variable (Y) equal to one used if the firm employs Repurchase DRIPs and zero for adopting no DRIPs. The sample includes all firms initiating DRIPs using "open market purchased" shares as reported in the $18^{\text {th }}$ edition of the Directory of Companies Offering Dividend Reinvestment Plans, 2000. To address the question of why some firms and not others offer Repurchase DRIP, we create a control sample of firms that paid dividends, but did not initiate DRIP during the sample period. We matched the sample firms (USERS) with control firms (NONUSERS) with the same four-digit SIC code whose market value of equity most closely matched the sample firm's equity at the end of the fiscal year preceding the year of the sample firm's initiation of Repurchase DRIP. The data of all independent variables are available from the RESEARCH INSIGHT (COMPUSTAT) during the sample period (1996-2000).

The independent variables are all measured as three-year average, four-year average, and five-year average respectively before sample firms establish their own DRIPs. The independent variables are all measured as three-year average, four-year average, and five-year average respectively before sample firms establish their own DRIPs. The variables are a percentage of insider ownership (INSIDER), free cash flow (CFC), firm size (SIZE), and market to book value of equity (MB). Table 1 provides the predicted signs of the coefficients to be estimated for variables hypothesized as incentives to employ Repurchase DRIPs. 


\section{Table 1: Summary Of Explanatory Variables And Their Predicted Signs Of Coefficient Estimates}

Predicted signs of coefficient estimates for variables used as proxies for incentives to choose open market repurchase dividends reinvestment plans (Repurchase DRIPs)) based on the testable implications of our hypotheses. Variable names appear in the second column. Predicted signs appear in the third column.

\begin{tabular}{lcc}
\hline Independent Variables & Variable Name & Prediction \\
\hline Market-to-Book Ratio & MB & Positive \\
$\%$ of Insider Ownership & INSIDER & Negative \\
Free Cash Flow: & FCF & Positive \\
Firm Size & SIZE & Positive \\
\hline
\end{tabular}

\section{EMPIRICAL RESULTS}

\section{Univariate Tests}

Table 2 presents summary statistics for the explanatory variables used in the previous sections and t-statistics from tests of differences between the means of the variables for users and nonusers of Repurchase DRIPs. The univariate tests suggest that users of Repurchase DRIPs are statistically different from nonuser firms with respect firm size, information asymmetry, and free cash flows. Firms' size is significantly larger than that of nonuser. In addition, Repurchase DRIP users also have larger free cash flow holdings than do nonusers. Difference in information asymmetry between DRIP users and nonusers is marginally significant at 10 percent level. But managerial share holdings of DRIP users are not significantly different from those of nonusers. As we note in the next section, managerial ownership is statistically significant in logit regressions for this sample. Table 3 presents the Pearson correlation coefficients between the independent variables.

\section{Table 2: Summary of Financial Characteristics of Repurchase DRIP Users and Nonusers}

This table reports selected summary statistics for managerial and financial characteristics for firms that disclose the use of Repurchase DRIPs (USERS), and firms that do not (NONUSERS). All the data are five-year averages (1996 - 2000). The tstatistics are given for tests of the equality of means between USERS and NONUSERS.

\begin{tabular}{|c|c|c|c|c|c|c|c|c|}
\hline \multirow[b]{2}{*}{ Variable } & \multicolumn{3}{|c|}{ All Firms $(n=748)$} & \multicolumn{2}{|c|}{$\underline{\operatorname{USERS}}(\mathrm{n}=374)$} & \multicolumn{2}{|c|}{ NONUSERS $(n=374)$} & \multirow[b]{2}{*}{ t-statistics } \\
\hline & Mean & Median & $\overline{\text { Std Dev }}$ & Mean & Std Dev & Mean & Std Dev & \\
\hline Free Cash Flows & $\begin{array}{l}100.456 \\
(\mathrm{~N}=674)\end{array}$ & 118.550 & 617.76 & $\begin{array}{l}197.98 \\
(\mathrm{~N}=340)\end{array}$ & 179.98 & 39.573 & $\begin{array}{l}376.24 \\
(\mathrm{~N}=342)\end{array}$ & $2.365 * * *$ \\
\hline Market to Book Ratio & $\begin{array}{l}3.535 \\
(\mathrm{~N}=690)\end{array}$ & 2.239 & 10.869 & $\begin{array}{l}4.250 \\
(\mathrm{~N}=351)\end{array}$ & 7.5198 & 2.7843 & $\begin{array}{l}13.446 \\
(\mathrm{~N}=339)\end{array}$ & $1.775^{*}$ \\
\hline Firm Size & $\begin{array}{l}3.147 \\
(\mathrm{~N}=724)\end{array}$ & 3.141 & 0.862 & $\begin{array}{l}3.349 \\
(\mathrm{~N}=371)\end{array}$ & 0.821 & 2.935 & $\begin{array}{l}0.853 \\
(\mathrm{~N}=353)\end{array}$ & $6.654 * * *$ \\
\hline$\%$ of Insider Ownership & $\begin{array}{l}7.004 \\
(\mathrm{~N}=515)\end{array}$ & 1.465 & 21.431 & $\begin{array}{l}6.818 \\
(\mathrm{~N}=270)\end{array}$ & 13.356 & 7.179 & $\begin{array}{l}22.409 \\
(\mathrm{~N}=240)\end{array}$ & -0.191 \\
\hline
\end{tabular}

Notes: $* * *, * *$, and $*$ represent significance at the $1 \%, 5 \%$, and $10 \%$ levels, respectively. $\mathrm{t}$-statistics are from mean-difference tests between sample and control firms.

\section{Logit Results}

We estimate logit regressions to distinguish the different motivations for Repurchase DRIPs adoption. Table 4 explores the determinants of firm's decision to offer Repurchase DRIPs. A dichotomous variable represents Repurchase DRIPs adoption on the explanatory variables for 5-year averages. The dependent variable is equal to one for Repurchase DRIPs users and zero for nonusers. As shown by the result of regression in Table 4, all the explanatory variables enter the regression with the hypothesized signs. Among the variables, firm size, managerial 
share holdings, and free cash flow provide statistically significant explanatory powers for the Repurchase DRIP adoption. The significantly positive relationship between firm size and the likelihood of using Repurchase DRIP suggests that larger firms are more likely to use Repurchase DRIPs. The costs associated with implementing a DRIP strategy do play a role in a firm's decision to adopt Repurchase DRIPs as firm size is a proxy for economies of scale in the costs of initiating and maintaining Repurchase DRIPs. Managerial controls are also an important factor in the decision to use Repurchase DRIPs because the likelihood of using Repurchase DRIPs is negatively related to a percentage of insider holdings. A higher percentage of insider holdings, which indicates the presence of more internally available voting power, implies a significantly lower probability of adopting DRIPs, and vice versa. The positive coefficient estimate of free cash flows indicates that Repurchase DRIP is a good mean of distributing excess capital since stock repurchase and dividend payments are offered to investors at the same time. We find no evidence that information asymmetry has a direct bearing on the likelihoods of using Repurchase DRIPs.

In order to check the robustness of the model, we estimate two additional logit regressions for both types of DRIPs over two different time periods ( 3 year and 4 year averages, respectively). The results are very similar to 5-year average regressions but they are not reported in this paper.

\section{Table 3: Pearson Correlation Coefficients}

This table contains the Pearson correlation coefficients for explanatory variables used in the logit regressions.

\begin{tabular}{|c|c|c|c|c|}
\hline & Free Cash Flows & $\begin{array}{l}\text { Market to Book } \\
\text { Ratio }\end{array}$ & Log Firm Size & $\begin{array}{l}\% \text { of Insider } \\
\text { Ownership }\end{array}$ \\
\hline$\overline{\text { Free Cash Flows }}$ & 1.000 & & & \\
\hline Market to Book Ratio & $0.073^{*}$ & 1.000 & & \\
\hline Firm Size & $0.282 * * *$ & $0.173 * * *$ & 1.000 & \\
\hline$\%$ of Insider Ownership & $0.310 * * *$ & $0.222 * * *$ & $0.285^{* * *}$ & 1.000 \\
\hline
\end{tabular}

Notes: $* * *, * *$, and $*$ represent significance at the $1 \%, 5 \%$, and $10 \%$ levels, respectively.

Table 4: Logit Regression Estimates of the Likelihood of Adopting Repurchase DRIPs Using Five-Year Averages (1996-2000)

The following logit regressions estimate the relationship between the likelihood of a firm using Repurchase DRIPs and the proxies for incentives to adopt them. The second column presents the signs of the coefficients estimates based on the testable implications of corporate finance theory. The values of the proxies are averages of the five years between 1996 and 2000 . t-statistics in parentheses are for the logit coefficients.

\begin{tabular}{lcc}
\hline Variables & Predicted Sign & Logit Model \\
\hline Intercept & & -2.835 \\
& & $(-6.169)^{* * *}$ \\
Free Cash Flows & Positive & 0.001 \\
& & $(2.041)^{* *}$ \\
Market to Book Ratio & Positive & 0.008 \\
& & $(0.699)$ \\
Firm Size & Positive & 0.954 \\
& & $(6.319)^{* * *}$ \\
\% of Insider Ownership & Negative & -0.0138 \\
N & & $(-2.579)^{* * *}$ \\
$-2 *$ Log Likelihood & & 468 \\
Model Chi-Square & & 581.532 \\
\hline
\end{tabular}

Note: $* * *, * *$, and $*$ denote significance at the $1 \%, 5 \%$, and $10 \%$ level, respectively. 


\section{CONCLUSIONS}

We examine the determinants of firm's decision to offer Repurchase DRIPs from the perspectives of financial managers. The results of the multivariate tests between Repurchase DRIP users and nonusers indicate that firm size, managerial share holding, and free cash flow are statistically significant in explaining a firm's decision to use Repurchase DRIPs. We find that managerial stock ownership is negatively related to use of Repurchase DRIPs. This result is consistent with the hypothesis that Repurchase DRIPs can be used as a vehicle of maintaining the control over the firm. The costs associated with implementing and maintaining DRIPs strategy do play a role in a firm's decision to adopt Repurchase DRIPs. Excess cash flows are positively related to Repurchase DRIP adoption. We find no evidence that information asymmetry is a major motivation to the likelihoods of using Repurchase DRIPs.

\section{REFERENCES}

1. Bajaj, M. and A. Vijh, 1990. Dividend clienteles and the information content of dividend changes. Journal of Financial Economics 26, 193-219.

2. Baker, H. K. and W. H. Seippel, 1980. Dividend Reinvestment Plans Win Wide Currency. Harvard Business Review 1980, 182-186.

3. Berry, K., 2000. Dividend Reinvestment: Capitalists \& Financers. New York Times 150, 925-984, the New York Times Company, New York.

4. $\quad$ Bierman, H., 1997. The Dividend Reinvestment Puzzle. Applied Financial Economics 7, 267-271.

5. Carlson, C., 1992. A Lot for (Almost) Nothing: The Lure of Dividend Reinvestment Plans. Barron's February 17, 1992: 17.

6. Cherin, A. C. and R. C. Hanson, 1995. Dividend Reinvestment Plans: A Review of the Literature. Financial Markets, Institutions and Instruments 4, 59-73.

7. Davey, P.J., 1976. Dividend Reinvestment Programs. The Conference Board Report 1976.

8. Denis, D., D. Denis, and A. Sarin 1994. Information content of dividend changes: Cash flow, signaling, overinvestment, and dividend clienteles. Journal of Financial and Quantitative Analysis 29, 567-587.

9. $\quad$ Ditter, A.K., 2000. Why Do Firms Repurchase Stock? The Journal of Business 73, 331-355.

10. Dubosky, D. A. and L. Bierman, 1988. The Effect of Discount Dividend Reinvestment Plans Announcements on Equity Value. Akron Business and Economic Review 19, 58-68.

11. Evergreen Enterprise LLC, 2000. The $18^{\text {th }}$ edition of the Directory of Companies Offering Dividend Reinvestment Plans.

12. Fox, D. L., 1981. Directory of Dividend Reinvestment Plans 1981 Edition.

13. Geczy, C., B. A. Minton, and C. Schrand, 1997. Why Firms Use Currency Derivatives. Journal of Finance 52, 1323-1354.

14. Hagaman, T. C., 1990. Raising Capital through DRPs. Management Accounting 72, 14-15.

15. Healy, P. and K. Palepu, 1988, Earning Information Conveyed by Dividend Initiations. Journal of Financial Economics 21, 149-175.

16. Jensen, M. C., 1986. Agency costs of free cash flow. American Economic Review 76, 323-329.

17. Jensen, G. R., D. P. Solberg, and T. S. Zorn, 1992. Simultaneous Determination of Insider Ownership, Debt, and Dividend Policies. Journal of Financial and Quantitative Analysis 27, 247-263.

18. Kaplan, S., and D. Reishus, 1990. Outside directorships and corporate performance. Journal of Financial Economics 27, 389-410.

19. Lucas, D. and R. McDonald, 1990. Equity Issues and Stock Price Dynamics. Journal of Finance 45, 10191043.

20. Miller, M.H. and K. Rock, 1985. Dividend Policy Under Asymmetric Information. Journal of Finance 40, 1031-1051.

21. Myers, S.C. and N. S. Majluf, 1984. Corporate Financing and Investment Decisions When Firms Have Information That Investors Do Not. Journal of Financial Economics 13, 187-221.

22. Nance, D. R., Smith, C. W., and C. W. Smithson, 1993. On the determinants of corporate hedging. Journal of Finance 48, 267-284.

23. Opler, T. and S. Titman, 1996. The debt-equity choice: An analysis of issuing firms. Working paper. Columbia: Ohio State University. 
24. Pettway, R. H. and R. P. Malone, 1973. Automatic Dividend Reinvestment Plans of Nonfinancial Corporations. Financial Management 1973, 11-18.

25. Peterson, P. P., D. R. Peterson, and N. H. Moore, 1987. The Adoption of New-Issue Dividends Reinvestment Plans and Shareholder Wealth. Financial Review 22, 212-232.

26. Perumpral, S., A. J. Keown, and J. Pinkerton, 1991. Market Reaction to the Formulation of Automatic Dividend Reinvestment Plans. Review of Business and Economic Research 1991, 48-58.

27. Roden, F. and T. Stripling, 1996. Dividend Reinvestment Plans as Efficient Methods of Raising Equity Financing. Review of Financial Economics 5, 91-100.

28. Rodgers, P., 1980. Dividend Reinvestment Plans and Proposed Tax Law Changes. National Association of Regulatory Utility Commissioners, Washington, D.C.

29. Rozeff, M. S., 1982. Growth, Beta and Agency Costs As Determinants of Dividend Payout Ratios. Journal of Financial Research 3, 249-259.

30. Scholes, M. S. and M. A. Wolfson, 1989. Decentralized Investment Banking: The Case of Discount Dividend-Reinvestment and Stock-Purchase Plans. Journal of Financial Economics 24, 7-35. 


\section{NOTES}

